\title{
Relationship between the Career Selection Process and Happiness among Japanese School Teachers, Office Workers, and Nurses
}

\author{
Nozomu Mandai1,2*, Jun Sato ${ }^{2}$, Mayumi Watanabe ${ }^{3,4}$, Aki Ibe ${ }^{1}$, Simon R. Downes ${ }^{5}$, \\ Hiroyuki Umiyama ${ }^{2}$, Atsuko Uchinuno ${ }^{1}$ \\ ${ }^{1}$ Faculty of Nursing Science, Tsuruga Nursing University, Tsuruga, Japan \\ ${ }^{2}$ Ibaraki Prefectural University of Health Sciences, Ibaraki, Japan \\ ${ }^{3}$ Kansai University of Health Sciences, Osaka, Japan \\ ${ }^{4}$ Faculty of Science and Engineering, Chuo University, Tokyo, Japan \\ ${ }^{5}$ Avalon University School of Medicine, Willemstad, Curaçao \\ Email: ^n-mandai@tsuruga-nu.ac.jp
}

How to cite this paper: Mandai, N., Sato J., Watanabe, M., Ibe, A., Downes, S.R., Umiyama, H. and Uchinuno, A. (2022) Relationship between the Career Selection Process and Happiness among Japanese School Teachers, Office Workers, and Nurses. Health, 14, 236-245.

https://doi.org/10.4236/health.2022.142018

Received: January 17, 2022

Accepted: February 22, 2022

Published: February 25, 2022

Copyright $\odot 2022$ by author(s) and Scientific Research Publishing Inc. This work is licensed under the Creative Commons Attribution International License (CC BY 4.0)

http://creativecommons.org/licenses/by/4.0/

\begin{abstract}
Background: Happiness varies across the life course in a U shape, with the least happiness in mid-life during the working years. Therefore, choosing a career may be an important factor in life's happiness. However, the relationship between the career selection process and happiness remains unclear. Methods: We surveyed 805 schoolteachers, office workers, and nurses from an available marketing database using an ad hoc questionnaire assessing happiness and career selection type. Results and Discussion: We found that happiness was significantly greater among schoolteachers and nurses than for office workers in Japan. Furthermore, among schoolteachers and office workers, an evasive/avoidance type of career-selection process had an unfavorable effect on happiness. However, among nurses, no such association was observed. Conclusion: Paying attention to the career-selection process may be helpful to improve happiness.
\end{abstract}

\section{Keywords}

Happiness, Career Selection, Nursing, Teaching, Survey

\section{Introduction}

Japan has one of the highest life expectancies among advanced economies, [1] and life expectancy in Japan is expected to continue to increase. Human life currently lasts about 100 years, with improvements in health, nutrition, medical 
care, sanitation, education, and other aspects of life expected to further increase longevity [2]. A study reported that half of the children born in Japan 10 years ago will live to be 107 years old [1]. As life expectancy increases, so does the proportion of life spent engaged in employment (working life expectancy). Japan is known for its traditional social structures, with predetermined life courses and career paths [3]. While the government of Japan has been working toward a society in which all citizens are engaged and has made investments in human resources to reform work styles, workers in many fields are regularly expected to work overtime, and overtime work is associated with psychological stress [4]. Job stress has been linked to adverse mental health outcomes in various fields, including among social workers, eldercare workers, and public employees [5] [6] [7]. Indeed, several studies have noted greater job dissatisfaction in Japan compared with other countries [8] [9] [10].

Substantial differences in subjective well-being exist from country to country, and Japan is less happy than other countries, ranking below most other industrialized nations [11] [12]. Happiness differs across the life course, and studies report a U-shaped association of happiness with age, with the trough in the middle of the working years [13] [14]. research suggests that gains in life expectancy in Japan since 1995 have been large gains in years of poor self-rated health. Understanding the relationship between career factors and happiness is important for improving overall well-being among Japanese.

Career satisfaction is also known to differ by occupation, with employees gaining more satisfaction from jobs that involve providing experiences to customers instead of objects [15]. While nursing is an arduous occupation, requiring long working hours and the completion of complex tasks in often unhealthy work environments, nurses report job satisfaction in contributing to others' wellbeing and saving lives [16]. Likewise, schoolteachers may derive job satisfaction from how they contribute to their students' futures and well-being, and teachers' happiness and self-esteem are mediated by their job satisfaction [17]. As professions that provide experiences to clients, nursing and teaching may afford greater happiness than the product-centered occupations of office workers.

To clarify the relationship between the career-selection process and happiness, we surveyed subjects from an available marketing database using an ad hoc questionnaire.

\section{Methods}

\subsection{Participants}

We analyzed the relationship between the career selection process and happiness for each of the occupations of a school teacher, office worker, and nurse. Participants were recruited from a database that is administered by a Japanese survey company (Cross Marketing Inc., Tokyo, Japan). From a total of 4,200,000 people listed in a database administered by this company, a subsample of 805 subjects was drawn using random sampling stratified by age and place of residence. All 
participants used a web-based questionnaire-answering system provided by the survey company. All 805 subjects who accessed the survey web page responded and gave us informed consent before starting the questionnaire. This study was approved by the Medical Ethics Committee of Ibaraki Prefectural University of Health Sciences (Ibaraki, Japan, e136-h300104).

\subsection{Happiness Score}

In this study, we measured self-perceived happiness using the following single question: "How would you rate your overall happiness level on an 11-point scale of zero (very unhappy) to ten (very happy)?" This single-item scale is reliable, valid, and correlated with self-rated physical and mental health [18].

\subsection{Type of Career Selection Process}

We also explored characteristics of the career-selection process in medical sciences students examined in terms of psychological traits relating to important decisionmaking. The career selection process was evaluated using the following single question: "How did you decide on your profession?" Participants chose among five types of career selection, as shown in Table 1. Career-selection types were modeled on course-selection types that were previously verified via factor analysis. [19] The full questionnaire is also available in the Appendix.

\subsection{Statistical Analysis}

The cross-sectional comparison began with a performance of the Levene test to determine the equality of variance among the groups. Based on the results, the means of the parameters of the groups were compared using either one-way ANOVA or Welch's test, as appropriate. To correct for the level of significance, the Games-Howell test was performed to compare the mean values among the groups. We used Statistical Package for the Social Sciences (SPSS) ver.27.0 (SPSS, Inc., Chicago, IL, USA) for all statistical analysis. The statistical significance level was set at $\mathrm{p}<0.05$.

Table 1. Career selection types able types.

\begin{tabular}{ll}
\hline Career selection Type & Characterization \\
Early-selection & $\begin{array}{l}\text { Since I was a child, I vaguely thought about my current profession, imagined myself in that profession, } \\
\text { and told others around me, so my intentions strengthened and I decided almost as I wanted. }\end{array}$ \\
Midway change & $\begin{array}{l}\text { There was a profession that I had decided on, but there was a big conflict due to grades, opposition from } \\
\text { others, or other factors, so I changed it. }\end{array}$ \\
Just-prior selection & $\begin{array}{l}\text { It was not clear what kind of profession I would take until just before the course was decided, and I } \\
\text { decided just before that, but I accept the decided course. }\end{array}$ \\
Evasion & $\begin{array}{l}\text { I went with the flow of life that happened at that time, without knowing which profession to take. The } \\
\text { vision for the future was not very clear. }\end{array}$ \\
Encounter & $\begin{array}{l}\text { One day when I was in high school, I learned about this profession and have been thinking about taking } \\
\text { up this profession ever since. }\end{array}$ \\
\hline
\end{tabular}




\section{Results}

\subsection{The Average Happiness Level of School Teachers, Office Workers, and Nurses}

We compared the average happiness level of schoolteachers, office workers, and nurses (Table 2 and Figure 1). We found that the average happiness level of office workers (mean 5.6; standard deviation [SD], 2.3) was significantly lower than that of schoolteachers (mean 6.4; SD, 2.2) and nurses (mean 6.7; SD, 2.3) (both $p$ $<0.001$ ). Happiness did not significantly differ between teachers and nurses $(\mathrm{p}=$ $0.527)$.

\subsection{Career Selection Process Types and Happiness Level}

We also compared career selection process types and average happiness levels for each occupation (Table 3). The happiness levels of office workers (Figure 2(a)) and schoolteachers (Figure 2(b)) were significantly lower for the evasion type than for other types of career selection (ANOVA $p<0.001$; individual comparison $p$ values ranged from $p<0.001$ to $p=0.046$ ). However, no such relationship was observed among nurses (Figure 2(c)), for whom happiness level did not differ significantly between types (ANOVA $\mathrm{p}=0.138$ ).

Table 2. Comparison of mean self-reported happiness rating among occupations.

\begin{tabular}{cc}
\hline Occupation & N Mean \pm SD \\
Schoolteacher & $2736.4 \pm 2.2$ \\
Office worker & $3885.6 \pm 2.3$ \\
Nurse & $1446.7 \pm 2.3$ \\
\hline
\end{tabular}

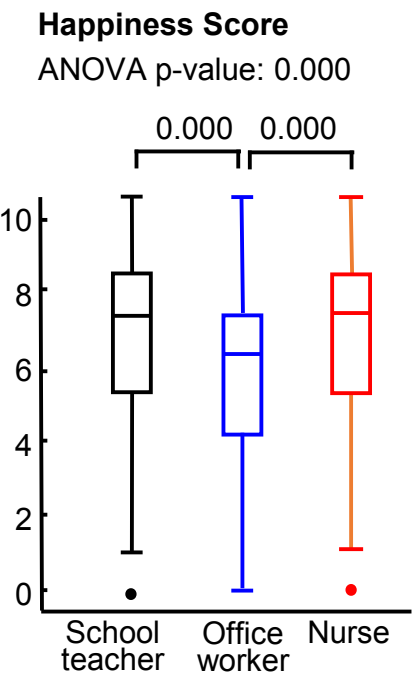

Figure 1. Happiness rating among occupations. The average happiness level of office workers was significantly lower than school teachers and nurses. Happiness did not significantly differ between teachers and nurses. 
Table 3. Mean self-reported happiness ratings stratified by career-selection type of mean self-reported happiness rating among occupations.

\begin{tabular}{cccccc}
\hline \multirow{2}{*}{$\begin{array}{c}\text { Type } \\
\text { Occupation }\end{array}$} & $\begin{array}{c}\text { Early } \\
\text { selection }\end{array}$ & $\begin{array}{c}\text { Midway } \\
\text { change }\end{array}$ & $\begin{array}{c}\text { Just-prior } \\
\text { selection }\end{array}$ & Evasion & Encounter \\
\cline { 2 - 6 } & N Mean \pm SD N Mean \pm SD N Mean \pm SD N Mean \pm SD N Mean \pm SD \\
\hline Schoolteacher & $1266.6 \pm 2.2$ & $366.3 \pm 1.7$ & $626.7 \pm 2.1$ & $214.4 \pm 2.7$ & $286.7 \pm 2.1$ \\
Office worker & $475.7 \pm 2.2$ & $286.0 \pm 1.9$ & $1656.1 \pm 2.0$ & $1134.4 \pm 2.4$ & $56.0 \pm 1.9$ \\
Nurse & $726.9 \pm 2.3$ & $256.6 \pm 2.7$ & $216.9 \pm 1.8$ & $95.0 \pm 1.9$ & $176.2 \pm 1.7$ \\
Total & $2456.5 \pm 2.2$ & $896.3 \pm 2.1$ & $2486.3 \pm 2.0$ & $1434.4 \pm 2.4$ & $806.3 \pm 1.9$ \\
\hline
\end{tabular}

Happiness Score

(a) Office worker ANOVA p-value: 0.000

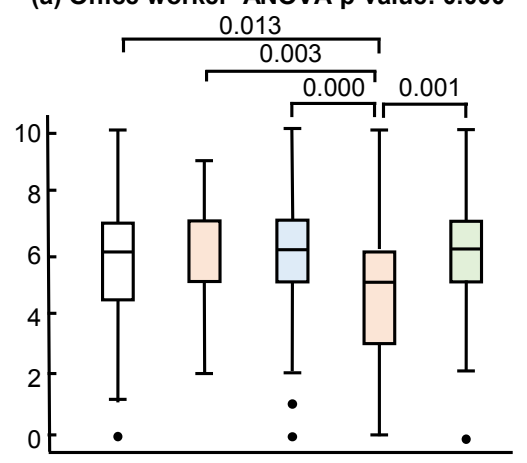

(b) Schoolteacher ANOVA p-value: $\mathbf{0 . 0 0 0}$

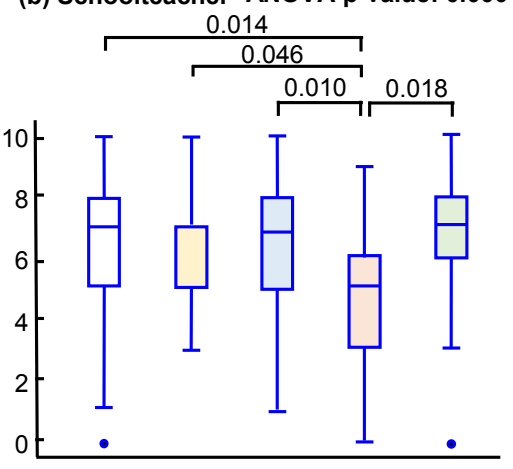

(c) Nurse ANOVA p-value: 0.138

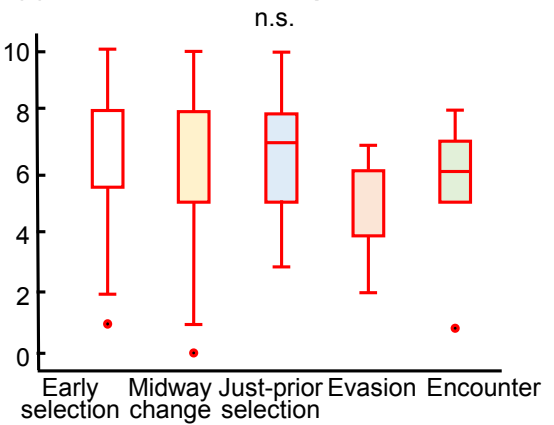

Figure 2. Happiness rating score among occupations. The happiness levels of office workers (a) and schoolteachers (b) were significantly lower for the evasion type than for other types of career selection. However, no such relationship was observed among nurses (c). 


\section{Discussion}

We found that happiness was significantly greater among schoolteachers and nurses than among office workers in Japan. Among schoolteachers and office workers, an evasive/avoidance type of career-selection process had an unfavorable effect on happiness. However, among nurses, no such association was observed.

Happiness varies across the life course and may be influenced by many factors, and individuals make trade-offs in levels of happiness with levels of income, physical health, family, career success, and education [20].

Career satisfaction is also known to differ by occupation. Nurses report job satisfaction related to the meaningfulness of their work to the lives and wellbeing of their patients [21]. Likewise, schoolteachers may derive job satisfaction from how they contribute to their students' futures and well-being, and teachers' happiness and self-esteem are mediated by their job satisfaction [22]. As professions that provide experiences to clients, nursing and teaching can afford greater happiness than the product-centered occupations of office workers.

Career satisfaction is further influenced by motivating career factors, including task identity, skill variety, task significance, autonomy, and feedback [22]. Nursing and teaching are occupations requiring a range of skills and ownership of autonomous tasks, and the work contributes to patients/students' health and wellbeing throughout the life course. These motivating factors may contribute to happiness among nurses and schoolteachers.

Career decision-making across the life span is influenced by a wide spectrum of external factors, [23] including family influence, academic satisfaction, and self-efficacy [24]. Self-efficacy related to career planning is itself influenced by other personality traits, including neuroticism, agreeableness, and conscientiousness [25]. Gender differences have been shown in career self-efficacy, with the perception of barriers in career development leading to less career planning among girls [26].

An evasive/avoidance career-selection type was associated with less happiness among schoolteachers and office workers. Neglecting to actively choose an occupation may lead to a perceived lack of autonomy and task significance in their occupations. Self-determination is a stronger determinant of perceived wellbeing than income or educational background [14]. An evasive career selection type may also reflect personality traits associated with less career satisfaction. The lack of an observed association between the evasion career-selection type and happiness among nurses may also be related to personality traits or other external factors, but could also be due to the small group size for that category ( $\mathrm{n}=$ 9). Indeed, the point estimate for happiness among nurses reporting an evasive/ avoidance career-selection type was lower than that for other career-selection types (5.0 vs. $6.2-6.9)$. It is possible that a significant association would be clear in a larger sample.

Career education programs have been shown to increase self-efficacy and en- 
courage active career exploration in re-cent graduates, [27] as well as improving career self-efficacy, career adaptability, and career stress in nursing students [28]. Given the negative association of an evasive/avoidance career-selection type with happiness, interventions to improve career-related self-efficacy are warranted.

\section{Conclusion}

We found that Japanese nurses and schoolteachers reported greater happiness than office workers and that an evasive career-selection strategy is detrimental to happiness among schoolteachers and office workers. Paying attention to the career-selection process may be helpful to improve happiness.

\section{Acknowledgements}

We thank all volunteers who participated in this study.

\section{Ethics Approval}

This study was approved by the Medical Ethics Committee of Ibaraki Prefectural University of Health Sciences (Ibaraki, Japan, e136-h300104).

\section{Conflicts of Interest}

The authors declare no conflicts of interest regarding the publication of this paper.

\section{References}

[1] Japan Cabinet Office (2017) New Economic Policy Package. https://www5.cao.go.jp/keizai1/package/20171208_package_en.pdf

[2] Gratton, L. and Scotto, A. (2016) The 100-Year Life: Living and Working in an Age of Longevity. Broomsbury, London.

[3] Sugimoto, Y. (2020) An Introduction to Japanese Society. Cambridge University Press, Cambridge.

[4] Furihata, R., Kuwabara, M., Oba, K., Watanabe, K., Takano, N., Nagamine, N., et al. (2021) Association between Working Overtime and Psychological Stress Reactions in Elementary and Junior High School Teachers in Japan: A Large-Scale CrossSectional Study. Industrial Health, Article ID: 2021-0069.

https://doi.org/10.2486/indhealth.2021-0069

[5] Ishikawa, Y., Kohara, M. and Nushimoto, A. (2021) Job Stress and Mental Health among Social Workers: Evidence from a Field Experiment at a Public Employment Support Institution in Japan. The Japanese Economic Review, 73, 123-146. https://doi.org/10.1007/s42973-021-00100-Z

[6] Yamauchi, T., Yoshikawa, T., Sasaki, T., Matsumoto, S., Takahashi, M., Suka, M. and Yanagisawa, H. (2018) Cerebrovascular/Cardiovascular Diseases and Mental Disorders Due to Overwork and Work-Related Stress among Local Public Employees in Japan. Industrial Health, 56, 85-91. https://doi.org/10.2486/indhealth.2017-0131

[7] Tsuboi, Y., Ueda, Y., Naruse, F. and Ono, R. (2017) The Association between Perceived Stress and Low Back Pain among Eldercare Workers in Japan. Journal of Occupational and Environmental Medicine, 59, 765-767.

https://doi.org/10.1097/JOM.0000000000001062 
[8] Nagai, M., Tsuchiya, K. J., Toulopoulou, T. and Takei, N. (2007) Poor Mental Health Associated with Job Dissatisfaction among School Teachers in Japan. Journal of Occupational Health, 49, 515-522. https://doi.org/10.1539/joh.49.515

[9] Oshio, T. (2021) Job Dissatisfaction as a Predictor of Poor Health among MiddleAged Workers: A 14-Wave Mixed Model Analysis in Japan. Scandinavian Journal of Work, Environment \& Health, 47, 591-599.

https://doi.org/10.5271/sjweh.3985

[10] Tatsuse, T. and Sekine, M. (2013) Job Dissatisfaction as a Contributor to StressRelated Mental Health Problems among Japanese Civil Servants. Industrial Health, 51, 307-318. https://doi.org/10.2486/indhealth.2012-0058

[11] Diener, E., Diener, M. and Diener, C. (1995) Factors Predicting the Subjective WellBeing Of Nations. Journal of Personality and Social Psychology, 69, 851-864. https://doi.org/10.1037/0022-3514.69.5.851

[12] Diener, E. and Suh, E.M. (2003) National Differences in Subjective Well-Being. In: Subjective Well-Being. Well-Being. The Foundations of Hedonic Psychology, Russell Sage Foundation, New York.

[13] Tiefenbach, T. and Kohlbacher, F. (2013) Happiness from the Viewpoint of Economics: Findings from Recent Survey Data in Japan. Working Paper 13/1, German Institute for Japanese Studies (DIJ), Tokyo. http://www.dijtokyo.org/publications/WP1301_Tiefenbach_Kohlbacher.pdf

[14] Nishimura, K. and Yagi, T. (2019) Happiness and Self-Determination-An Empirical Study in Japan. Review of Behavioral Economics, 6, 312-346.

https://doi.org/10.1561/105.00000113

[15] Bastos, W. and Barsade, S.G. (2020) A New Look at Employee Happiness: How Employees' Perceptions of a Job as Offering Experiences versus Objects to Customers Influence Job-Related Happiness. Organizational Behavior and Human Decision Processes, 161, 176-187. https://doi.org/10.1016/j.obhdp.2020.06.003

[16] Franco, M.F., Farah, B.F., Amestoy, S.C., Thofehrn, M.B. and Porto, A.R. (2021) Meaning of Work from the Perspective of Hospital Nurses. Revista Brasileira de Enfermagem, 75, Article ID: e20201362. https://doi.org/10.1590/0034-7167-2020-1362

[17] Benevene, P., Ittan, M.M. and Cortini, M. (2018) Self-Esteem and Happiness as Predictors of School Teachers' Health: The Mediating Role of Job Satisfaction. Frontiers in Psychology, 9, Article No. 933. https://doi.org/10.3389/fpsyg.2018.00933

[18] Abdel-Khalek, A.M. (2006) Measuring Happiness with a Single-Item Scale. Social Behavior and Personality: An International Journal, 34, 139-150. https://doi.org/10.2224/sbp.2006.34.2.139

[19] Yoko, H. and Yoshiyuki, O. (2004) Characteristics of the Course-Selection Process in Medical Sciences Students Examined in Terms of Peychological Traits Relating to Important Decision-Making. Tsukuba Psychological Research, 28, 79-87.

[20] Adler, M.D., Dolan, P. and Kavetsos, G. (2017) Would You Choose to Be Happy? Tradeoffs between Happiness and the Other Dimensions of Life in a Large Population Survey. Journal of Economic Behavior \& Organization, 139, 60-73. https://doi.org/10.1016/j.jebo.2017.05.006

[21] Oerlemans, W.G. and Bakker, A.B. (2018) Motivating Job Characteristics and Happiness at Work: A Multilevel Perspective. Journal of Applied Psychology, 103, 1230-1241. https://doi.org/10.1037/apl0000318

[22] Pan, J. and Zhou, W. (2013) Can Success Lead to Happiness? The Moderators between Career Success and Happiness. Asia Pacific Journal of Human Resources, 51, 
63-80. https://doi.org/10.1111/j.1744-7941.2012.00033.x

[23] Duffy, R.D. and Dik, B.J. (2009) Beyond the Self: External Influences in the Career Development Process. The Career Development Quarterly, 58, 29-43. https://doi.org/10.1002/j.2161-0045.2009.tb00171.x

[24] Koçak, O., Ak, N., Erdem, S.S., Sinan, M., Younis, M.Z. and Erdoğan, A. (2021) The Role of Family Influence and Academic Satisfaction on Career Decision-Making Self-Efficacy and Happiness. International Journal of Environmental Research and Public Health, 18, Article No. 5919. https://doi.org/10.3390/ijerph18115919

[25] Feldt, R.C. and Woelfel, C. (2009) Five-Factor Personality Domains, Self-Efficacy, Career-Outcome Expectations, and Career Indecision. College Student Journal, 43, 429-438.

[26] Cardoso, P. and Moreira, J.M. (2009) Self-Efficacy Beliefs and the Relation between Career Planning and Perception of Barriers. International Journal for Educational and Vocational Guidance, 9, Article No. 177. https://doi.org/10.1007/s10775-009-9163-2

[27] Tarigan, M. and Wimbarti, S. (2011) Career Planning Program to Increase Career Search Self Efficacy in Fresh Graduates. Journal of Higher Education Theory and Practice, 11, 75-87.

[28] Park, H.M. and Lee, H.S. (2015) The Effects of Career Education Program on Career Self-Efficacy, Career Adaptability and Career Stress for Nursing Students. The Journal of the Korea Contents Association, 15, 304-312.

https://doi.org/10.5392/JKCA.2015.15.08.304 


\section{Appendix (Questionnaire)}

- Age (years)

Age (years)

Q What is your age group?

$\square 20$ - $29 \square 30-39 \square 40-49 \square 50$ - 59

- Gender

Q Your gender

$\square$ male $\square$ female

- Job

Q Please select your profession.

$\square$ school teacher $\square$ office worker $\square$ nurse

- Decision-Making

Q How did you decide on your profession? Please select an applicable answer.

$\square$ early-selection type: Since I was a child, I vaguely thought about my current profession, imagined myself in that profession, and told others around me, so my intentions strengthened and I decided almost as I wanted.

$\square$ midway change type: There was a profession that I had decided on, but there was a big conflict due to grades, opposition from others, or other factors, so I changed it.

$\square$ just-prior selection type: It was not clear what kind of profession I would take until just before the course was decided, and I decided just before that, but I accept the decided course.

$\square$ evasive type: I went with the flow of life that happened at that time, without knowing which profession to take. The vision for the future was not very clear.

$\square$ encounter type: One day when I was in high school, I learned about this profession and have been thinking about taking up this profession ever since.

\section{- Happiness}

Q How would you rate your overall happiness level of zero (very unhappy) to ten (very happy)?

$\square 0 \square 1 \square 2 \square 3 \square 4 \square 5 \square 6 \square 7 \square 8 \square 9 \square 10$ 